\title{
Forest Stand Management and Biomass Growth
}

\author{
Angela Lo Monaco ${ }^{1, *} \mathbb{C}$ and Paolo Cantiani ${ }^{2}$ \\ 1 Department of Agriculture and Forest Sciences (DAFNE), University of Tuscia, Via S. Camillo de Lellis, \\ 01100 Viterbo, Italy \\ 2 Research Centre for Forestry and Wood (CREA), Viale Santa Margherita 80, 50121 Arezzo, Italy; \\ paolo.cantiani@crea.gov.it \\ * Correspondence: lomonaco@unitus.it
}

Citation: Lo Monaco, A.; Cantiani, P. Forest Stand Management and Biomass Growth. Forests 2021, 12, 1253. https://doi.org/10.3390/ f12091253

Received: 6 September 2021 Accepted: 9 September 2021 Published: 15 September 2021

Publisher's Note: MDPI stays neutral with regard to jurisdictional claims in published maps and institutional affiliations.

Copyright: (c) 2021 by the authors. Licensee MDPI, Basel, Switzerland. This article is an open access article distributed under the terms and conditions of the Creative Commons Attribution (CC BY) license (https:// creativecommons.org/licenses/by/ $4.0 /)$.
Forests are natural or semi-natural systems that can generate services and products that humans use directly or indirectly. Forest management involves economic, legal, and social aspects, as well as scientific and technical aspects. This includes management for wood or non-wood products, ecosystem services, dead wood, and other forest resource values, such as recreation, tourism, water, and wildlife, as well as biomass for energy and carbon accumulation, also taking into account the increase in the rate of climate change in the coming years. Timber harvesting, plantation of tree species, roads, and pathways through forests should be in synergy with forest management. The goal of this Special Issue was to provide a compendium of documents that scientifically evaluate the effects of different sustainable management approaches on services and products expected from forests, with respect to the environment and biodiversity maintenance. This was the message inviting colleagues to collaborate to the development of knowledge on this topic.

The contribution to the Special Issue comprises 19 articles by authors involved in university, research institutions, and agencies, from nine countries from Asia, Europe, and America. The articles deal with agroforestry [1], natural forests [2-12], and forest plantations [13-19].

A wide range of species is considered: Magnolia wufengensis L.Y.Ma and L.R.Wang [2], Fagus orientalis Lipsky and Acer velutinum Boiss. [4], Pinus pinea L. and Mediterranean oaks [5], Castanea sativa Mill. [6], Fagus orientalis Lipsky, Carpinus betulus L., Acer velutinum Boiss., Acer cappadocicum Gled., Tilia Begonifolia Stev., Quercus castanifolia C.A. Mey., Ulmus glabra Huds. and Alnus subcordata C.A. Mey. as the principal species of a mixed deciduous forest [7], Fagus sylvatica L. [9,11], Mangroves (Laguncularia racemosa (L.) C.F.Gaertn., Avicennia germinans (L.) L. and Rhizophora mangle L.) [12], Sapindus mukorossi Gaertn. [17], Picea abies (L.) H.Karst. [3], Cunninghamia lanceolata (Lamb.) Hook. [4,16], Pinus sylvestris L. [10,15], Pinus taeda L. [14], Pinus nigra J.F.Arnold [18], Pinus rigida Mill. and the understory Quercus variabilis Blume, Quercus acutissima Carruth., Quercus mongolica Fisch. ex Ledeb, Quercus serrata Murray, and Carpinus laxiflora Siebold and Succ. Blume [19], and more than 370 species and shrubs from Jianfengling Forest Reserve on Hainan Island in southern China [8].

The multifunctional role of forests and agroforestry systems as a model of sustainable development for rural areas was analysed in [1], a review of dossiers of 59 sites already included in the globally important agricultural heritage systems (GIAHS) programme of Food and Agriculture Organisation (FAO). The original research articles offer a wide range of aspects related to the management of forests and plantations, as well as to parameters useful in explaining biomass growth, also considering the urban forest. The collection provides an illustration of research activities on the impacts of stand management on the growth of stems and root systems $[2-4,8,10,13]$ and on soil $[4,6-8]$. The articles deal with damage to residual trees during thinning operations [14]; regeneration in a mixed deciduous forest [4] in a coppiced stand [6], and in a coniferous plantation [16]; carbon sequestration both in a protected lowland forest in Italy [5] and in a pine plantation 
in Korea [15]; and fertility in terms of maintenance of soil fertility in plantations [16] and fertilization management for seedling growing in greenhouse [2]. Quantitative and qualitative data on the deadwood in three types of lowland Mediterranean forest of a protected area provide useful information for sustainable management in production forests [5]. The legacy of disturbance is highlighted both in a tropical rainforest [8] and in a European beech forest [9], as well as the impact of stand density and tree social status, which is determined in terms of biomass of stems, living and dead branches, cones, and foliage in a Scots pine forest [10]. The description of the phenology of Sapindus mukorossi, a multifunctional tree, is proposed [17] as this species has interest for ecological and aesthetic values in landscaping and for its fruits used as raw materials for bioenergy and saponin production. Tree growth dynamics and environmental factors explored along the Italian latitudinal gradient are illustrated in [11] for a 5-year monitoring time in beech forests. The article [18] on the taper function for Pinus nigra from Central Italy can be conveniently used to develop estimation procedures of stem profile for assortment evaluation useful in the wood products supply chain. The study [19] demonstrates the important contribution of naturally regenerated understory tree biomass to total biomass in pine plantations and explains that the biomass growth characteristics of understory vegetation can vary greatly with dominant species; therefore, care should be taken when adopting allometric equations developed elsewhere and for larger trees. The structure and composition of mangrove forests across urban gradients in Puerto Rico are studied in [12].

Some papers present results that can be immediately useful for forest managers. The influence of stand density on biomass allocation is emphasised on premature and mature stands [9] and on the natural renovation after shelterwood cutting with varying intensity [8]. The recovery period of soil after forest logging is crucial for the sustainability of forest management. This topic is detailed for coppice [6], plantation [14], and high forest [4,7] in this Special Issue.

Clearly, these 19 articles do not exhaust the topic of forest management and biomass growth. Indeed, it can be said that these articles provide examples of certain aspects of the relationship between biomass growth and forest stand management that deserve to be addressed in the key to sustainability for the development of the well-being of populations that live on forest products and benefit of forest services.

With this occasion, we thank the authors who contributed to this Special Issue, the reviewers who helped us to significantly improve the quality of each of the published articles, and the editorial board and staff who kindly supported us in this endeavour.

Author Contributions: All authors contributed to the writing of this editorial. All authors have read and agreed to the published version of the manuscript.

Funding: This research received no external funding.

Institutional Review Board Statement: Not applicable.

Informed Consent Statement: Not applicable.

Data Availability Statement: Not applicable.

Conflicts of Interest: The authors declare no conflict of interest.

\section{References}

1. Santoro, A.; Venturi, M.; Bertani, R.; Agnoletti, M. A Review of the Role of Forests and Agroforestry Systems in the FAO Globally Important Agricultural Heritage Systems (GIAHS) Programme. Forests 2020, 11, 860. [CrossRef]

2. Deng, S.; Shi, K.; Ma, J.; Zhang, L.; Ma, L.; Jia, Z. Effects of Fertilization Ratios and Frequencies on the Growth and Nutrient Uptake of Magnolia wufengensis (Magnoliaceae). Forests 2019, 10, 65. [CrossRef]

3. Štícha, V.; Sharma, R.; Vacek, Z.; Vacek, S.; Nuhlíček, O. Timber and Branch Volume Prediction: Effects of Stand and Site Characteristics on Dendromass and Timber-To-Branch Volume Ratio of Norway Spruce in Managed Forests. Forests 2019, 10, 144. [CrossRef] 
4. Picchio, R.; Tavankar, F.; Nikooy, M.; Pignatti, G.; Venanzi, R.; Lo Monaco, A. Morphology, Growth and Architecture Response of Beech (Fagus orientalis Lipsky) and Maple Tree (Acer velutinum Boiss.) Seedlings to Soil Compaction Stress Caused by Mechanized Logging Operations. Forests 2019, 10, 771. [CrossRef]

5. Lo Monaco, A.; Luziatelli, G.; Latterini, F.; Tavankar, F.; Picchio, R. Structure and Dynamics of Deadwood in Pine and Oak Stands and their Role in $\mathrm{CO}_{2}$ Sequestration in Lowland Forests of Central Italy. Forests 2020, 11, 253. [CrossRef]

6. Venanzi, R.; Picchio, R.; Grigolato, S.; Spinelli, R. Soil Disturbance Induced by Silvicultural Treatment in Chestnut (Castanea sativa Mill.) Coppice and Post-Disturbance Recovery. Forests 2020, 11, 1053. [CrossRef]

7. Sohrabi, H.; Jourgholami, M.; Tavankar, F.; Venanzi, R.; Picchio, R. Post-Harvest Evaluation of Soil Physical Properties and Natural Regeneration Growth in Steep-Slope Terrains. Forests 2019, 10, 1034. [CrossRef]

8. Bu, W.; Zhang, C.; Huang, J.; Zang, R.; Ding, Y.; Xu, H.; Lin, M.; Wang, J. The Influences of Disturbance Histories and Soil Properties on Aboveground Biomass through Plant Functional Traits in a Tropical Rainforest. Forests 2019, 10, 774. [CrossRef]

9. Konôpka, B.; Barna, M.; Bosela, M.; Lukac, M. Biomass Allocation to Resource Acquisition Compartments Is Affected by Tree Density Manipulation in European Beech after Three Decades. Forests 2020, 11, 940. [CrossRef]

10. Wertz, B.; Bembenek, M.; Karaszewski, Z.; Ochał, W.; Skorupski, M.; Strzeliński, P.; Wegiel, A.; Mederski, P. Impact of Stand Density and Tree Social Status on Aboveground Biomass Allocation of Scots Pine Pinus sylvestris L. Forests 2020, 11, 765. [CrossRef]

11. Ferrara, C.; Marchi, M.; Fabbio, G.; Fares, S.; Bertini, G.; Piovosi, M.; Salvati, L. Exploring Nonlinear Intra-Annual Growth Dynamics in Fagus sylvatica L. Trees at the Italian ICP-Forests Level II Network. Forests 2019, 10, 584. [CrossRef]

12. Branoff, B.; Martinuzzi, S. The Structure and Composition of Puerto Rico's Urban Mangroves. Forests 2020, 11, 1119. [CrossRef] [PubMed]

13. Farooq, T.; Wu, W.; Tigabu, M.; Ma, X.; He, Z.; Rashid, M.; Gilani, M.; Wu, P. Growth, Biomass Production and Root Development of Chinese fir in Relation to Initial Planting Density. Forests 2019, 10, 236. [CrossRef]

14. Tavankar, F.; Nikooy, M.; Lo Monaco, A.; Latterini, F.; Venanzi, R.; Picchio, R. Short-Term Recovery of Residual Tree Damage during Successive Thinning Operations. Forests 2020, 11, 731. [CrossRef]

15. Zhang, X.; Zhang, X.; Han, H.; Shi, Z.; Yang, X. Biomass Accumulation and Carbon Sequestration in an Age-Sequence of Mongolian Pine Plantations in Horqin Sandy Land, China. Forests 2019, 10, 197. [CrossRef]

16. Duan, A.; Lei, J.; Hu, X.; Zhang, J.; Du, H.; Zhang, X.; Guo, W.; Sun, J. Effects of Planting Density on Soil Bulk Density, pH and Nutrients of Unthinned Chinese Fir Mature Stands in South Subtropical Region of China. Forests 2019, 10, 351. [CrossRef]

17. Zhao, G.; Gao, Y.; Gao, S.; Xu, Y.; Liu, J.; Sun, C.; Gao, Y.; Liu, S.; Chen, Z.; Jia, L. The Phenological Growth Stages of Sapindus mukorossi According to BBCH Scale. Forests 2019, 10, 462. [CrossRef]

18. Marchi, M.; Scotti, R.; Rinaldini, G.; Cantiani, P. Taper Function for Pinus nigra in Central Italy: Is a More Complex Computational System Required? Forests 2020, 11, 405. [CrossRef]

19. Han, S.; Park, B. Comparison of Allometric Equation and Destructive Measurement of Carbon Storage of Naturally Regenerated Understory in a Pinus rigida Plantation in South Korea. Forests 2020, 11, 425. [CrossRef] 